\title{
A Comparison of Components and Biological Activities Between the Hot Water Extracts of Achyranthes japonica Nakai and Achyranthes bidentata Blume
}

\author{
Ye-Seul Lee, Mi-Sun Kim, Ha-Young Kwon and Ho-Yong Sohn* \\ Department of Food and Nutrition, Andong National University, Andong 760-749, Korea \\ Received February 10, 2014 /Revised May 12, 2014 / Accepted May 21, 2014
}

\begin{abstract}
Woosul (Achyranthis radix), a widely used material in food and oriental medicinal industry, has different origins of plant species in Korea, Japan and China. In Korea, woosul is designated as the radix of Achyranthes japonica Nakai (AJN) and Achyranthes bidentata Blume (ABB) in the regulation of The Korean Pharmacopoeia. However, the comparative study of hot water (HW) extracts between AJN and $\mathrm{ABB}$ is still rudimentary. In this study, HW extracts and its subsequent organic solvent fractions of $\mathrm{AJB}$ and $\mathrm{ABB}$ were prepared, and their in-vitro antimicrobial, antioxidant and anti-diabetes activities were evaluated. The HW extract of $\mathrm{ABB}$ has higher sugars and polyphenol compounds, and higher lightness and lower yellowness compared than those of AJN. Analysis of biological activities showed that the ethylacetate (EA) fraction of AJN and n-hexane fraction of ABB have antibacterial activities, and the EA fractions of $\mathrm{AJN}$ and $\mathrm{ABB}$ has strong antioxidation activities determined by radical scavenging activity and reducing power. In anti-diabetes activity assay, the EA fractions of AJN and ABB showed a-amylase inhibitory activities, while the butanol fractions of AJN and ABB showed a-glucosidase inhibitory activities. Our results suggest that the HW extracts of AJB and ABB have different components and extraction yields, and their subsequent fractions have different biological activity. Therefore it was concluded that the EA fraction of AJN is appropriate to develop as natural medicine, and the HW extract of AJN is suitable to woosul-tea or woosul-sikhye production.
\end{abstract}

Key words : Achyranthes bidentata Blume, Achyranthes japonica Nakai, bioactivity, hot-water extract

\section{서 론}

우슬은 한국, 중국, 일본 등에 분포하는 비름과(Amaranthaceae)의 다년생 식물로, 식물줄기 마디의 형상이 소의 무릎과 유사하여 쇠무릎이라고도 불리며, 우경, 백배, 산현채, 계교골 등으로 불린다 $[4,8]$. 우슬의 뿌리는 식용 및 약용으로 이용되 고 있으며, 특히 한방에서는 관절염의 치료 및 완화 $[8,10,20]$, 신장과 간장에 작용하여 어혈 제거, 혈액순환 촉진, 혈액 생성 및 열을 떨어뜨리는 용도로 사용하고 있다[16, 23]. 우슬은 국 가마다 기원식물이 다른데, 한국의 경우 토우슬(Achyranthes japonica Nakai), 중국의 경우 회우슬(Achyranthes bidentata Blume), 천우슬(Cyathula officinalis Kuan) 및 마우슬(Cyathula capitata Moq)을 사용하고 있으며, 일본에서는 회우슬과 털우 슬(Achyranthes fauriei H.)을 주로 사용하고 있다[12, 14]. 국내 에서는 식용 및 약용으로 사용 가능한 우슬을 토우슬 및 회우 슬로 규정하고 있으며, 현재 우리나라 대한약전에서도 국내

\footnotetext{
*Corresponding author

Tel : +82-54-820-5491, Fax : +82-54-820-7804

E-mail : hysohn@anu.ac.kr

This is an Open-Access article distributed under the terms of the Creative Commons Attribution Non-Commercial License (http://creativecommons.org/licenses/by-nc/3.0) which permits unrestricted non-commercial use, distribution, and reproduction in any medium, provided the original work is properly cited
}

자생하는 토우슬과 중국산의 회우슬의 2종을 우슬로 규정하 고 있다[12]. 국내에서는 많은 연구가 토우슬에 집중되어 있으 나, 중국을 포함한 전 세계적으로는 회우슬에 대한 연구가 주 로 이루어지고 있다.

현재 우슬의 주요 약리성분으로는 oleanolic acid, inocosterone, ecdysterone, beta-sitosterol, stigmasterol, feruloyl tyramine glycoside 등이 알려져 있으며[30], 우슬의 지표물질 검정 및 분석연구[32]와 우슬 추출물의 안정성 연구[18]가 최 근 진행되었으나, 아직까지 한국에서는 우슬 지표성분 함량은 설정되어 있지 않다. 우슬에 대한 연구는, 우슬의 형태적 분류 [12] 및 대량증식을 위한 기내배양 연구[15]에서 우슬의 유용 생리활성 탐색과 이를 이용한 식의약품 소재개발 연구로 전환 되고 있다 $[4,28]$. 대표적인 우슬의 유용 생리활성으로는 항산 화 활성 $[5,24]$, 항균[3, 6] 및 항말라리아 활성[33], 항염증 활성 $[2,17]$, 산화적 스트레스에 따른 간 독성 보호효과[13], 카드뮴 흡입시의 해독효과 $[7,9]$, 관절염 완화 및 경조직 재생효과 $[8$, 19], 파골세포 분화억제효과 $[4,10]$, 허혈성 뇌손상 모델에서의 $\mathrm{PC} 12$ 세포의 보호효과[23] 및 혈전생성 억제 및 혈류개선 효과 $[16,29]$ 등이 알려져 있다.

현재까지 토우슬과 회우슬의 비교연구는 주로 형태 분류 [12]에 집중되어 있으며, 생리활성 비교연구로는 토우슬과 회 우슬의 메탄올 추출물의 DPPH (1,1-diphenyl-2-picryl hydra$\mathrm{zyl}$ ) 음이온 소거활성과 간암세포 및 자궁경부암 세포에 대한 
항암활성 검정[31] 및 토우슬, 회우슬을 각각 물, 에탄올, 메탄 올 등의 다양한 용매로 추출한 추출물들의 항산화 효과 비교 [24]가 보고되어 있으며, 최근 토우슬과 회우슬의 에탄올 추출 물의 항균, 항산화 및 항당뇨 활성 비교[21]가 보고되어 있을 뿐이다. 현재 국내에서 토우슬과 회우슬이 모두 우슬이란 이 름으로 식용 및 약용으로 사용되고 있으며, 이들을 열수로 추 출하여 우슬차 및 우슬 혈부축어탕[16] 등으로 이용되고 있음 을 고려할 때, 토우슬 및 회우슬의 열수 추출물의 성분 및 효능 평가가 필요하다고 판단된다.

따라서 본 연구에서는 우슬을 이용한 우슬차 및 우슬식혜 개발 연구의 일환으로, 국내산 토우슬과 중국산 회우슬의 열 수 추출물 및 이의 순차적 유기용매 분획물을 조제하여 각각 의 유용성분을 분석하고, 추출물 및 분획물의 in-vitro항균 활 성, 항산화 활성 및 항당뇨 활성을 비교하여 보고하는 바이다.

\section{재료 및 방법}

\section{실험재료 및 시료의 조제}

본 실험에 사용된 국내산 토우슬과 중국산 회우슬은 2012년 안동지역의 대제한약에서 구입하여 사용하였다. 국내산 토우 슬은 2011년 경북 영천에서 가을에 수확, 건조한 제품이며, 중국산 회우슬은 2011년 중국 하남성에서 가을에 수확, 건조 한 제품이다. 각각의 우슬은 추출에 적합하도록 세절한 후 증 류수를 우슬 무게의 20 배가 되도록 첨가하여 $100^{\circ} \mathrm{C}$ 에서 2 시간 추출하였으며, 상기 추출을 3 회 반복하였다. 이후 추출액은 filter paper (Whatsman No. 2)로 거른 후 감압 농축(Eyela Rotary evaporator N-1000, Tokyo Rikakikai Co., Ltd. Japan) 하여 분말로 조제하였다. 유기용매 분획물 제조의 경우, 각각 의 우슬 열수 추출물을 물에 현탁한 후 n-hexane, ethylacetate 및 butanol을 이용하여 순차적으로 분획하고 물 잔류물을 회 수하였으며[1], 각각의 분획물들은 감압 건조하여 분말화하였 다. 각각의 시료들은 $\mathrm{DMSO}$ 에 적당한 농도로 녹여, in-vitro 항균 활성, 항산화 활성 및 항당뇨 활성 평가에 사용하였다. 기타 사용한 시약은 시약급 이상으로 Sigma Co. (MO, USA)의 제품을 구입하여 사용하였다. 실험에 사용한 우슬은 안동대학 교 식품영양학과에서 보관하고 있다(voucher specimen 2012WS1, 2012-WS2).

\section{항균 활성}

조제된 우슬의 열수 추출물 및 이의 분획물의 항균 활성은 기존의 보고된 방법과 동일하게 평가하였다[11]. 항세균 활성 평가를 위한 그람 양성세균으로는 Staphylococcus aureus KCTC 1916, Listeria monocytogenes KACC 10550, Bacillus subtilis KCTC 1924를 사용하였으며, 그람 음성세균으로는 Escherichia coli KCTC 1682, Proteus vulgaris KCTC 2433, Salmonella typhimurium KCTC 1926를 사용하였고, 항진균 활성 평가를 위해
서는 Candida albicans KCTC 1940및 Saccharomyces cerevisiae IF0 0233를 사용하였다. 항세균 활성 평가의 경우, Nutrient broth (Difco Co., USA)에 각각의 세균을 접종하여 $37^{\circ} \mathrm{C}$ 에서 24시간 동안 배양한 후, 각 균주를 O.D.600 0.1로 조정하여 Nutrient agar (Difco Co., USA) 배지를 포함하는 멸균 petri dish $(90 \times 15$ mm, Green Cross Co., Ltd. Korea)에 $100 \mu l$ 도말 하고, 각각의 시료 $5 \mu \mathrm{l}$ 를 멸균 disc-paper (지름 $6.5 \mathrm{~mm}$, Whatsman No.2)에 첨가하여, $37^{\circ} \mathrm{C}$ 에서 24 시간 동안 배양하 였으며, 진균의 경우에는 Sabouraud dextrose agar (Difco Co. USA) 배지를 이용하여 동일한 방법으로 $30^{\circ} \mathrm{C}$ 에서 24 시간 동 안 배양 후, 생육저지환의 크기를 측정하여 항균활성을 평가 하였다[11]. 대조구로는 항세균제인 ampicillin과 항진균제인 miconazole (Sigma Co., USA)을 각각 $1 \mu \mathrm{g} / \mathrm{disc}$ 의 농도로 사 용하였으며, 생육저지환의 크기는 육안으로 생육이 나타나지 않는 부분의 지름을 $\mathrm{mm}$ 단위로 측정하였고, 3 회 이상 평가 후 대표 결과로 나타내었다.

\section{항산화 활성}

조제된 우슬 열수 추출물 및 분획물은 dimethylsulfoxide (DMSO)에 녹인 후 적당한 농도로 희석하여 항산화 활성을 평가하였으며, 항산화 활성은 1,1-diphenyl-2-picryl hydrazyl $(\mathrm{DPPH})$ anion 소거능, 2,2-azobis (3-ethylbenzothiazoline6-sulfonate) (ABTS) cation 소거능 및 환원력을 측정하여 평가 하였다[26]. 대조구로는 vitamin C (Sigma Co., USA)를 사용 하였으며, 용매 대조구로는 DMSO를 사용하였다. 각각의 활 성 평가는 각각 3회 이상 반복한 실험의 mean $\pm \mathrm{SD}$ 로 표시하 였으며, 소거능 평가에서 $50 \%$ 의 소거능이 나타나는 시료 농도 를 $\mathrm{IC}_{50}$ 로 나타내었다.

\section{DPPH Scavenging Activity (DSA)}

DSA평가는 기존의 보고한 방법[21]과 동일한 방법을 사용 하였다. 다양한 농도로 희석한 시료 $20 \mu \mathrm{l}$ 에 $99.5 \%$ 에탄올에 용해시킨 $2 \times 10^{-4} \mathrm{M} \mathrm{DPPH}$ 용액 $380 \mu \mathrm{l}$ 를 넣고 혼합하여 $37^{\circ} \mathrm{C}$ 에 서 30 분 동안 반응시킨 후, $516 \mathrm{~nm}$ 에서 microplate reader (Asys Hitech, Expert96, Asys Co., Austria)를 사용하여 흡광 도를 측정하고 다음의 식에 의해 DSA를 결정하였다[21].

DSA $(\%)=[1-(\mathrm{S} / \mathrm{C})] \times 100, \mathrm{C}:$ 용매 대조구 DMSO 첨가시의 흡광도, $\mathrm{S}$, 시료 첨가시의 흡광도.

\section{ABTS Scavenging Activity (ASA)}

$\mathrm{ASA}$ 평가를 위해 $7 \mathrm{mM} \mathrm{ABTS} \mathrm{(Sigma} \mathrm{Co.,} \mathrm{USA)} 5 \mathrm{ml}$ 와 $140 \mathrm{mM}$ potassium persulfate $88 \mu \mathrm{l}$ 를 섞은 후 상온에서 16시 간 빛을 차단하여 ABTS 양이온을 형성시켰으며, 이후 이 용액 을 $414 \mathrm{~nm}$ 에서 흡광도 값이 1.5 가 되도록 에탄올로 희석하였 다. 조제된 희석용액 $190 \mu \mathrm{l}$ 와 시료 $10 \mu 1$ 를 혼합한 후 상온에서 6분간 반응시킨 후 $734 \mathrm{~nm}$ 에서 흡광도를 측정하고 다음의 식 에 의해 $\mathrm{ASA}$ 를 결정하였다[21]. 
ASA $(\%)=(\mathrm{C}-\mathrm{S}) / \mathrm{C} x 100, \mathrm{C}$ : 용매 대조구 DMSO 첨가시의 흡광도, $\mathrm{S}$, 시료 첨가시의 흡광도.

\section{환원력 측정 (Reducing Power: RP)}

에탄올에 용해시킨 우슬 시료 $2.5 \mathrm{ml}$ 에 $0.2 \mathrm{M}$ sodium phosphate buffer ( $\mathrm{pH}$ 6.6) $2.5 \mathrm{ml}$ 와 10\% potassium ferricyanide $2.5 \mathrm{ml}$ 를 첨가하고 $50^{\circ} \mathrm{C}$ 에서 20 분 동안 반응시킨 후, $10 \%$ trichloroacetic acid $2.5 \mathrm{ml}$ 를 넣어 반응을 종료하고 $1,000 \mathrm{~g}$ 에서 10 분간 원심분리하여 상등액을 회수하였다. 회수한 상등액을 $0.1 \%$ ferric chloride 용액과 5:1 (v/v) 비율로 혼합하고 700 $\mathrm{nm}$ 에서 흡광도를 측정하여 환원력을 평가하였다[21].

Nitrite 소거활성 (Nitrite Scavenging Activity: NSA)

우슬 시료의 NSA평가를 위해, 아질산염 용액 $(1 \mathrm{mM})$ 에 시 료용액을 첨가하고, 여기에 $0.1 \mathrm{~N} \mathrm{HCl}$ 을 첨가해 $\mathrm{pH} 1.2$ 로 조 정한 후, $37^{\circ} \mathrm{C}$ 에서 1 시간 반응시킨 후 Griess reagent (Sigma Co., USA)를 첨가하고 혼합하였다. 이후 15 분간 실온에서 방 치 후 $520 \mathrm{~nm}$ 에서 흡광도를 측정하여 잔존 nitrite 양을 측정하 였다. NSA (\%)는 다음의 식에 의해 계산하였다[21].

NSA $(\%)=[1-(\mathrm{A}-\mathrm{C}) / \mathrm{B}] \times 100, \mathrm{~A}: 1 \mathrm{mM}$ nitrite 용액에 시료를 첨가하여 1 시간 반응시킨 후의 흡광도, $\mathrm{B}: 1 \mathrm{mM}$ nitrite 용액의 흡광도, $\mathrm{C}$ : 우슬 시료의 흡광도.

대조구로는 vitamin C (Sigma Co., USA)를 사용하였으며, 용매 대조구로는 $\mathrm{DMSO}$ 를 사용하였다. 각각의 활성 평가는 각각 3회 이상 반복한 실험의 mean $\pm \mathrm{SD}$ 로 표시하였으며, 소거능 평가에서 $50 \%$ 의 소거능이 나타나는 시료 농도를 $\mathrm{IC}_{50}$ 로 나타내었다.

\section{전분분해 저해 활성}

전분분해 저해활성은 활성은 in-vitro a-amylase 저해 활성 과 a-glucosidase 저해 활성을 평가하여 나타내었다. 먼저 aamylase 저해활성은 $\operatorname{Lim}$ 등[22]의 방법을 수정하여 사용하였 으며, 우슬 시료 $2.5 \mu 1$ 와 $50 \mathrm{mM}$ phosphate buffer ( $\mathrm{pH}$ 6.8)로 희석한 a-amylase $(0.25 \mathrm{U} / \mathrm{ml}) 25 \mu \mathrm{l}$ 를 혼합하여 $37^{\circ} \mathrm{C}$ 에서 10 분간 preincubation한 후, $0.5 \%$ soluble starch (Samchun Chemicals Co., Korea) $25 \mu 1$ 를 첨가하여 $37^{\circ} \mathrm{C}$ 에서 10 분간 반 응하였다. 이후 $100^{\circ} \mathrm{C}$ 에서 5 분간 가열하여 반응을 정지시켰으 며, 반응액에 $150 \mu 1$ 의 DNS (3,5-dinitrosalicylic acid, Sigma Co., USA) 용액을 첨가하여 $100^{\circ} \mathrm{C}$ 에서 5 분간 가열하여 발색한 후 상온에서 방냉하였다. 발색액은 96 well microplate reader (Tecan Co., USA)를 이용하여 $540 \mathrm{~nm}$ 에서 흡광도를 측정하였 으며, 각각의 실험은 3 회 반복한 후 평균값을 구하여 다음의 식으로 저해율을 계산하였다.

저해율 $(\%)=[1-($ 시료 첨가구 효소활성/대조구 첨가구 효 소활성)] $\times 100$.

a-glucosidase 저해활성은 pNPG (p-nitrophenol glucoside; Sigma Co., USA)를 이용하여 평가하였으며[22], 우슬 시료 2.5 $\mu 1$ 와 $50 \mathrm{mM}$ sodium acetate buffer $(\mathrm{pH}$ 5.6)로 희석한 a -glucosidase $(0.25 \mathrm{U} / \mathrm{ml}) 25 \mu \mathrm{l}$ 를 혼합하여 $37^{\circ} \mathrm{C}$ 에서 10 분간 preincubation 하고 $1 \mathrm{mM} \mathrm{pNPG}$ 용액 $25 \mu \mathrm{l}$ 를 가하여 $60^{\circ} \mathrm{C}$ 에 서 10 분간 반응하였다. 이후 $1 \mathrm{M} \mathrm{NaOH} 25 \mu \mathrm{l}$ 를 첨가하여 반응 을 정지시키고, $405 \mathrm{~nm}$ 에서 흡광도를 측정하여 저해율을 계산 하였다.

\section{기타 분석}

우슬의 수분함량은 적외선 수분측정기(HG53 Halogen Moisture Analyzer, Mettler-Toledo International Inc., Zurich, Switzerland)로 측정하였으며, 추출물의 $\mathrm{pH}$ 측정은 $320 \mathrm{pH}$ meter (Mettler Toledo InLabR 413, UK)로 측정하였다. 색차 측정은 색차계(Chromatometer CR-300, Minota, Japan)을 이 용하여 백색도(L value, lightness), 적색도(a value, redness) 및 황색도(b value, yellowness) 값을 3회 반복 측정하여 색차 $(\mathrm{E})$ 를 계산하였다. 표준 백색판은 $\mathrm{L}$ 값이 $92.39, a$ 값이 $-0.08, b$ 값 이 1.39 이었으며, 색차 $(\Delta E)$ 는 다음의 식을 이용하여 계산하였 다.

$$
\Delta E=\sqrt{(\Delta \mathrm{L})^{2}+(\Delta \mathrm{a})^{2}+(\Delta \mathrm{b})^{2}}
$$

한편 추출물의 총 flavonoid의 함량 측정은 기존의 보고한 방법[25]에 따라 측정하였으며, 각각의 시료를 18 시간 메탄올 교반 추출하고 여과한 추출검액 $400 \mu 1$ 에 $90 \%$ diethylene gly$\mathrm{col} 4 \mathrm{ml}$ 를 첨가하고 다시 $1 \mathrm{~N} \mathrm{NaOH} 40 \mu \mathrm{l}$ 를 넣고 $37^{\circ} \mathrm{C}$ 에서 1 시간 반응시킨 후 $420 \mathrm{~nm}$ 에서 흡광도를 측정하였다. 표준시 약으로는 rutin (Sigma Co., MO, USA)을 사용하였다. 총 polyphenol 함량은 추출검액 $400 \mu \mathrm{l}$ 에 $50 \mu \mathrm{l}$ 의 Folin-ciocalteau, $100 \mu \mathrm{l}$ 의 $\mathrm{Na}_{2} \mathrm{CO}_{3}$ 포화용액을 넣고 실온에서 1시간 방치한 후 $725 \mathrm{~nm}$ 에서 흡광도를 측정하였다[25]. 표준시약으로는 tannic acid (Sigma Co., MO, USA)를 사용하였다. 총당 정량의 경우 에는 phenol-sulfuric acid법을, 환원당 정량의 경우에는 DNS 변법을 이용하였다[27]. 각각의 분석결과는 3 회 반복한 실험의 평균과 편차로 나타내었다.

\section{통계 분석}

실험 결과는 SPSS 20.0 버전을 사용하여 mean \pm SD로 나타 내었으며, 각 군간의 차이는 ANOVA로 분석하였으며, Duncan 다중비교 검증법으로 통계적 유의성 검정을 조사하였다. 유의수준은 $p<0.05$ 로 하였다.

\section{결과 및 고찰}

\section{토우슬과 회우슬의 열수 추출물의 특성}

토우슬 및 회우슬의 수분함량은 각각 $9.13 \%$ 및 $10.89 \%$ 로 회우슬이 $1.7 \%$ 정도 수분함량이 높았으나, 열수 추출 효율은 토우슬이 $53.9 \%$ 로 회우슬의 $47.6 \%$ 보다 높았다(Table 1). 토우 슬 및 회우슬의 ethanol추출효율이 5.0 5.1\%인 점을 고려하면 
Table 1. Comparison of water content, yields of hot water extraction, and their $\mathrm{pH}$ and color differences between Achyranthes japonica Nakai (Korea) and A. bidentata Blume (China)

\begin{tabular}{cccccccc}
\hline \multirow{2}{*}{ Samples } & \multirow{2}{*}{ Water content $(\%)$} & \multirow{2}{*}{ Extraction yield $(\%)$} & $\mathrm{pH}$ & \multicolumn{4}{c}{ Color differences } \\
\cline { 5 - 8 } & & & L3 & $a 4$ & $b 5$ & $\Delta E 6$ \\
\hline $\mathrm{AJN}^{1}$ & $9.13 \pm 0.09$ & $53.9 \pm 2.05$ & $5.63 \pm 0.05$ & $44.9 \pm 2.0$ & $-5.5 \pm 0.7$ & $13.0 \pm 0.6$ & $49.2 \pm 1.8$ \\
$\mathrm{ABB}^{2}$ & $10.89 \pm 0.04^{*}$ & $47.6 \pm 0.82^{*}$ & $5.43 \pm 0.07$ & $51.2 \pm 0.3$ & $-4.8 \pm 0.0$ & $3.3 \pm 0.1$ & $41.5 \pm 0.3^{*}$ \\
\hline
\end{tabular}

${ }^{1} \mathrm{AJN}$ : Achyranthes japonica Nakai, ${ }^{2} \mathrm{ABB}$ : Achyranthes bidentata Blume. Data are presented as the mean $\pm \mathrm{SD}$ of three determinations. ${ }^{*} p<0.05$ compared with AJN. ${ }^{3} L$ : degree of lightness (white $+100 \sim 0$ black), ${ }^{4} a$. degree of redness (red $+100 \sim-80$ green), ${ }^{5} b$. degree of yellowness (yellow $+70 \sim-80$ black), ${ }^{6} \Delta \mathrm{E}$ : overall color difference $\left(\Delta \mathrm{E}=\sqrt{(\triangle L)^{2}+(\triangle a)^{2}+(\Delta b)^{2}}\right)$.

[21], 우슬의 열수 추출효율은 ethanol 추출에 비해 약 10 배 이상 높음을 알 수 있었다. 각각의 열수 추출물의 $\mathrm{pH}$ 는 5.43 5.63으로 유사하였으나, 색차의 경우 토우슬에서 회우슬 에 비해 상대적으로 낮은 명도, 적색도 및 높은 황색도를 나타 내어 색차는 토우슬에서 49.2 , 회우슬에서는 41.5 를 나타내었 다. 토우슬과 회우슬의 열수 추출물의 순차적 유기용매 분획 효율 및 성분 분석 결과는 Table 2에 나타내었다. 토우슬의 경우 n-hexane과 ethylacetate 분획의 총량이 $1.4 \%$ 로 매우 미 미하였으며, $77 \%$ 는 물 잔류물로 나타나 토우슬의 열수 추출물 의 대부분이 수용성 당류임을 알 수 있었다. 회우슬의 경우에 도 이와 유사하게 $\mathrm{n}$-hexane과 ethylacetate 분획의 총량이 $0.6 \%$ 로 매우 적었으며, 분획물 중 butanol 분획물과 물 잔류물 이 각각 $10.4 \%$ 및 $88.2 \%$ 로 나타났다. 한편 열수 추출물의 총당 및 환원당 함량은 회우슬 추출물이 토우슬보다 각각 1.86 및 1.1 배 높은 함량을 나타내었으며, 총폴리페놀 및 총플라보노 이드 함량은 회우슬 추출물이 토우슬보다 각각 1.58 및 9.3 배 높은 함량을 나타내었다. 관능성의 경우 우슬 특유의 향과 맛 은 토우슬이 우수하였으며, 회우슬의 경우 단맛이 너무 강하 였다.

한편 분획물의 총플라보노이드 및 총폴리페놀 함량 분석결
과, 토우슬 및 회우슬 모두에서 ethylacetate 분획에서 가장 높은 함량을 나타내었으나, 회우슬 분획에서 토우슬 분획보다 총플라보노이드 및 총폴리페놀 함량이 각각 3.3 배 및 7.4 배 높은 특성을 보였다. 총당 분석 결과, 토우슬의 모든 분획에서 는 153.32(n-hexane 분획) 382.27 mg/g (butanol 분획)의 함량 분포를 나타낸 반면 회우슬의 경우 9.86 (n-hexane 분획) $554.87 \mathrm{mg} / \mathrm{g}$ (물 잔류물)의 분포를 보였으며, 이러한 특성은 환원당 함량분석에서도 동일하게 나타났다. 따라서 회우슬이 토우슬보다 수용성 당류 및 다양한 폴리페놀 성분을 더욱 많 이 함유하고 있음을 확인하였다.

\section{토우슬과 회우슬의 항균활성 비교}

토우슬 및 회우슬의 열수 추출물 및 이의 순차적 유기용매 분획물의 항균활성 평가 결과는 Table 3에 나타내었다. 먼저 대조구로 사용된 ampicillin과 miconazole은 다양한 병원성 세균, 식중독 세균 및 진균에 우수한 항균활성을 나타내었다. 각각의 우슬 열수 추출물과 분획물 중 가장 많은 양을 차지하 는 물 잔류물은 항균 활성이 나타나지 않았다. 분획물 중 토우 슬의 ethylacetate 분획 $(500 \mu \mathrm{g} / \mathrm{disc})$ 에서는 대장균을 제외한 모든 세균에 대해 약한 항균력을 나타내었으며, n-hexane분획

Table 2. Comparison of the contents of total flavonoid, total polyphenol, total sugar and reducing sugar in hot water extracts and their fractions between Achyranthes japonica Nakai (Korea) and A. bidentata Blume (China)

\begin{tabular}{|c|c|c|c|c|c|c|}
\hline \multirow[b]{2}{*}{ Samples } & \multirow[b]{2}{*}{ Extract/Fraction } & \multirow[b]{2}{*}{$\begin{array}{l}\text { Fraction yield } \\
\qquad(\%)\end{array}$} & \multicolumn{4}{|c|}{ Content (mg/g-extract) } \\
\hline & & & $\begin{array}{c}\text { Total } \\
\text { flavonoid }\end{array}$ & $\begin{array}{c}\text { Total } \\
\text { polyphenol }\end{array}$ & $\begin{array}{l}\text { Total } \\
\text { sugar }\end{array}$ & $\begin{array}{l}\text { Reducing } \\
\text { sugar }\end{array}$ \\
\hline \multirow{5}{*}{$\mathrm{AJN}^{1}$} & Hot water $\mathrm{ex}^{3}$ & - & $0.09 \pm 0.01$ & $3.20 \pm 0.11$ & $354.80 \pm 0.16$ & $191.60 \pm 0.8$ \\
\hline & Hexane $\mathrm{fr}^{4}$ & 1.0 & $0.49 \pm 0.08$ & $3.26 \pm 0.15$ & $153.32 \pm 3.49$ & $123.19 \pm 3.01$ \\
\hline & Ethylacetate fr & 0.4 & $2.92 \pm 0.18$ & $4.72 \pm 0.19$ & $301.32 \pm 0.63$ & $59.28 \pm 2.52$ \\
\hline & Butanol fr & 17.7 & $0.10 \pm 0.01$ & $4.18 \pm 0.10$ & $382.27 \pm 0.63$ & $348.39 \pm 0.72$ \\
\hline & Water residue & 77.0 & $0.02 \pm 0.01$ & $2.67 \pm 0.11$ & $295.54 \pm 4.12$ & $134.92 \pm 0.36$ \\
\hline \multirow{5}{*}{$\mathrm{ABB}^{2}$} & Hot water ex & - & $0.84 \pm 0.03$ & $4.76 \pm 0.16$ & $662.8 \pm 3.61$ & $211.90 \pm 2.41$ \\
\hline & Hexane fr & 0.2 & $2.78 \pm 0.11$ & $3.64 \pm 0.06$ & $9.86 \pm 0.02$ & $6.78 \pm 0.48$ \\
\hline & Ethylacetate fr & 0.4 & $9.51 \pm 0.28$ & $34.95 \pm 1.83$ & $68.16 \pm 0.78$ & $23.88 \pm 0.04$ \\
\hline & Butanol fr & 10.4 & $0.86 \pm 0.07$ & $5.14 \pm 0.02$ & $475.08 \pm 5.08$ & $245.15 \pm 2.17$ \\
\hline & Water residue & 88.2 & $0.73 \pm 0.02$ & $3.58 \pm 0.03$ & $554.87 \pm 0.54$ & $192.79 \pm 5.06$ \\
\hline
\end{tabular}

${ }^{1} \mathrm{AJN}$ : Achyranthes japonica Nakai, ${ }^{2} \mathrm{ABB}$ : Achyranthes bidentata Blume, ${ }^{3}$ ex: extract, ${ }^{4}$ fr: fraction. Data are presented as the mean \pm $\mathrm{SD}$ of three determinations. 
Table 3. Comparison of the antimicrobial activity of hot water extracts and their fractions between Achyranthes japonica Nakai (Korea) and A. bidentata Blume (China)

\begin{tabular}{|c|c|c|c|c|c|c|c|c|c|}
\hline & \multirow{3}{*}{ Samples } & \multicolumn{8}{|c|}{ Antimicrobial activity (Clear zone: $\mathrm{mm}, 500 \mathrm{\mu g} /$ disc) } \\
\hline & & \multicolumn{3}{|c|}{ Gram positive bacteria } & \multicolumn{3}{|c|}{ Gram negative bacteria } & \multicolumn{2}{|c|}{ Fungi } \\
\hline & & $\mathrm{LM}^{5}$ & $\mathrm{SA}^{6}$ & $\mathrm{BS}^{7}$ & $\mathrm{EC}^{8}$ & $\mathrm{ST}^{9}$ & $\mathrm{PV}^{10}$ & $\mathrm{CA}^{11}$ & $\mathrm{SC}^{12}$ \\
\hline \multirow{5}{*}{$\mathrm{AJN}^{1}$} & Hot water ex ${ }^{3}$ & $\mathrm{NA}^{13}$ & NA & NA & NA & NA & NA & NA & NA \\
\hline & Hexane $\mathrm{fr}^{4}$ & NA & NA & 8 & NA & NA & NA & NA & NA \\
\hline & Ethylacetate $\mathrm{fr}$ & 7 & 7 & 11 & NA & 8 & 14 & NA & NA \\
\hline & Butanol fr & NA & NA & NA & NA & NA & NA & NA & NA \\
\hline & Water residue & NA & NA & NA & NA & NA & NA & NA & NA \\
\hline \multirow{5}{*}{$\mathrm{ABB}^{2}$} & Hot water ex & NA & $\mathrm{NA}$ & NA & $\mathrm{NA}$ & NA & NA & NA & NA \\
\hline & Hexane fr & NA & 11 & NA & NA & 9 & 9 & NA & NA \\
\hline & Ethylacetate fr & NA & NA & NA & NA & NA & 8 & NA & NA \\
\hline & Butanol fr & NA & NA & NA & NA & NA & NA & NA & NA \\
\hline & Water residue & NA & NA & NA & NA & NA & NA & NA & NA \\
\hline \multicolumn{2}{|c|}{ Ampicillin/Miconazole } & 25 & 22 & 30 & 11 & 17 & 30 & 13 & 18 \\
\hline
\end{tabular}

The concentration of ampicillin or miconazole used was $1.0 \mu \mathrm{g} / \mathrm{disc}$, respectively.

${ }^{1}$ AJN: Achyranthes Japonica Nakai, ${ }^{2}$ ABB: Achyranthes Bidentata Blume. ${ }^{3}$ ex: extract, ${ }^{4}$ fr: fraction. ${ }^{5}$ LM: Listeria Monocytogenes, ${ }^{6}$ SA: Staphylococcus Aureus, ${ }^{7} \mathrm{BS}$ : Bacillus Subtilis, ${ }^{8} \mathrm{EC}$ : Escherichia coli, ${ }^{9} \mathrm{ST}$ : Salmonella Typhimurium, ${ }^{10} \mathrm{PV}$ : Proteus Vulgaris, ${ }^{11} \mathrm{CA}:$ Candida Albicans, and ${ }^{12} \mathrm{SC}$ : Saccharomyces Cerevisiae, ${ }^{13} \mathrm{NA}$ : No Activity.

에서는 Bacillus subtilis에서만 항균력이 나타났다. 반면 회우슬 의 n-hexane분획에서는 대장균을 제외한 그람음성 세균 및 Staphylococcus aureus에 대한 항균 활성이 나타났으며, ethylacetate 분획에서는 Proteus vulgaris에 대한 활성이 나타났다. 따라서 토우슬에서는 ethylacetate 분획이, 회우슬에서는 n-hexane분획이 다양한 항균활성 물질을 포함하고 있음을 알 수 있었다.

\section{토우슬과 회우슬의 항산화능 비교}

토우슬 및 회우슬의 열수 추출물 및 분획물들의 항산화 활 성을 DSA, ASA 및 환원력 측정으로 평가한 결과는 Table 4에 나타내었다. 먼저 열수 추출물의 경우 토우슬이 회우슬보다 우수한 DSA 및 ASA를 나타내어 우슬의 유기용매 추출물과는 다른 결과를 나타내었다[21, 31]. 토우슬 및 회우슬의 분획물에 서는 모두 ethylacetate 분획에서 강력한 DSA 및 ASA를 나타 내었으며, 나머지 분획물의 항산화 활성은 미미하였다. 가장 강력한 항산화 활성은 토우슬 ethylacetate 분획에서 나타났으 며, ASA 경우 $0.5 \mathrm{mg} / \mathrm{ml}$ 농도에서 vitamin C $(0.01 \mathrm{mg} / \mathrm{ml})$ 에 필적하는 강력한 활성을 나타내었으며, $\mathrm{DSA}$ 의 경우 0.5 $\mathrm{mg} / \mathrm{ml}$ 의 농도에서 vitamin C $(0.01 \mathrm{mg} / \mathrm{ml})$ 에 비해 2배의 활 성을 나타내었다. 환원력 평가의 경우에도, 토우슬 ethylacetate분획에서 강력한 활성이 나타났으며, $0.5 \mathrm{mg} / \mathrm{ml}$ 농도 에서 회우슬의 ethylacetate 분획보다 3.2 배 강한 활성을 나타 내었다. 따라서 우슬의 열수 추출물의 경우, 메탄올 추출물[31] 또는 에탄올 추출물[21]과는 달리, 토우슬이 회우슬보다 우수 한 항산화력을 가지고 있음을 확인하였다.

한편 우슬 추출물 및 이의 분획물의 NSA 평가 결과는
Table 5에 나타내었으며, 항산화력 평가와 유사하게 각각의 추출물의 ethylacetate 분획에서 가장 양호한 활성을 나타내었 으며, 특히 토우슬의 ethylacetate 분획 $(0.1 \mathrm{mg} / \mathrm{ml})$ 은 대조구 로 사용된 vitamin C $(0.01 \mathrm{mg} / \mathrm{ml})$ 보다 우수한 활성을 나타 내었다. 토우슬의 경우 기타 다른 분획물 $(0.1 \mathrm{mg} / \mathrm{ml})$ 에서 $7.4 \sim 21.6 \%$ 의 소거능을 나타냈으며, 회우슬의 기타 분획에서는 14.5 26.5\% 의 NSA를 나타내었다. 이러한 결과는 우슬 열수 추출물이 다양한 nitrite 소거활성 물질을 함유하고 있음을 의 미하며, 우슬을 이용한 식품의 nitrite 소거제 개발이 가능함을 암시한다.

\section{토우슬과 회우슬의 전분 분해 저해활성 비교}

토우슬 및 회우슬의 열수 추출물 및 분획물들의 전분 분해 저해활성을 측정한 결과는 Table 6에 나타내었다. 먼저 임상에 서 사용되고 있는 acarbose (Sigma Co., MO, USA)는 0.1 $\mathrm{mg} / \mathrm{ml}$ 의 저농도에서 a-amylase 및 a-glucosidase 활성을 $49.4 \%$ 및 $55.2 \%$ 저해하여 우수한 항당뇨 활성을 확인하였다. 토우슬의 열수 추출물은 회우슬 추출물보다 우수한 a-amylase 저해활성을 나타내었으나, a-glucosidase 저해활성은 유 사하였다. 분획물의 경우 모든 분획물에서 유사한 a-amylase 및a-glucosidase 저해활성을 나타내었고, 토우슬의 경우 0.5 $\mathrm{mg} / \mathrm{ml}$ 농도에서 각각 8.1 15.4\% 및 9.3 11.6\%의 저해활성을 나타내었으며, 회우슬의 경우 각각 11.3 20.7\% 및 -1.9 15.8\% 의 저해활성을 나타내었다. 특히 우수한 a-amylase 저해활성 은 토우슬 및 회우슬의 ethylacetate 분획에서 나타났으나, aglucosidase 저해활성은 각각의 butanol 분획에서 나타나 다 양한 저해활성물질이 존재함을 확인하였다. 본 연구결과는 국 
Table 4. Comparison of the antioxidant activity of hot water extracts and their fractions between Achyranthes japonica Nakai (Korea) and $A$. bidentata Blume (China)

\begin{tabular}{|c|c|c|c|c|c|}
\hline & \multirow[b]{2}{*}{ Samples $(\mathrm{mg} / \mathrm{ml})$} & & \multicolumn{3}{|c|}{ Antioxidant activity (\%) } \\
\hline & & & $\begin{array}{c}\text { DPPH } \\
\text { scavenging activity }\end{array}$ & $\begin{array}{c}\text { ABTS } \\
\text { scavenging activity }\end{array}$ & $\begin{array}{l}\text { Reducing power } \\
\quad(700 \mathrm{~nm})\end{array}$ \\
\hline \multirow{10}{*}{${ }^{1} \mathrm{AJN}$} & \multirow{2}{*}{ Hot water ex ${ }^{3}$} & 0.5 & $5.3 \pm 0.7$ & $27.9 \pm 0.8$ & $0.078 \pm 0.005$ \\
\hline & & 1.0 & $6.5 \pm 1.1$ & $40.7 \pm 1.4$ & $0.210 \pm 0.002$ \\
\hline & \multirow{2}{*}{ Hexane $\mathrm{fr}^{4}$} & 0.5 & $1.6 \pm 0.1$ & $34.5 \pm 0.2$ & $0.075 \pm 0.002$ \\
\hline & & 1.0 & $3.7 \pm 0.8$ & $42.8 \pm 1.0$ & $0.166 \pm 0.002$ \\
\hline & \multirow{2}{*}{ Ethylacetate fr } & 0.5 & $69.5 \pm 2.4$ & $87.9 \pm 1.3$ & $0.614 \pm 0.007$ \\
\hline & & 1.0 & $74.2 \pm 1.2$ & $92.0 \pm 0.4$ & $0.954 \pm 0.001$ \\
\hline & \multirow{2}{*}{ Butanol fr } & 0.5 & $11.4 \pm 0.4$ & $40.2 \pm 1.4$ & $0.119 \pm 0.005$ \\
\hline & & 1.0 & $14.9 \pm 0.9$ & $53.0 \pm 1.2$ & $0.294 \pm 0.023$ \\
\hline & \multirow{2}{*}{ Water residue } & 0.5 & $0.4 \pm 0.8_{*}^{*}$ & $15.1 \pm 0.4$ & $0.039 \pm 0.004$ \\
\hline & & 1.0 & $3.6 \pm 0.9^{*}$ & $33.4 \pm 1.9$ & $0.136 \pm 0.006$ \\
\hline \multirow{10}{*}{${ }^{2} \mathrm{ABB}$} & \multirow{2}{*}{ Hot water ex } & 0.5 & $0.4 \pm 0.3$ & $21.7 \pm 1.1$ & $0.066 \pm 0.005$ \\
\hline & & 1.0 & $5.1 \pm 1.0$ & $29.4 \pm 0.5$ & $0.250 \pm 0.007$ \\
\hline & \multirow{2}{*}{ Hexane fr } & 0.5 & $0.1 \pm 0.6^{*}$ & $6.5 \pm 3.6$ & $0.094 \pm 0.002$ \\
\hline & & 1.0 & $7.7 \pm 1.5^{*}$ & $44.4 \pm 0.5$ & $0.276 \pm 0.007$ \\
\hline & \multirow{2}{*}{ Ethylacetate fr } & 0.5 & $31.5 \pm 0.1$ & $70.1 \pm 0.3$ & $0.190 \pm 0.011$ \\
\hline & & 1.0 & $35.8 \pm 2.0$ & $77.5 \pm 0.4$ & $0.397 \pm 0.008$ \\
\hline & \multirow{2}{*}{ Butanol fr } & 0.5 & $1.9 \pm 2.6$ & $20.8 \pm 0.6$ & $0.061 \pm 0.006$ \\
\hline & & 1.0 & $4.9 \pm 1.3$ & $37.4 \pm 0.1$ & $0.262 \pm 0.019$ \\
\hline & \multirow{2}{*}{ Water residue } & 0.5 & $1.0 \pm 2.5^{*}$ & $14.6 \pm 0.6$ & $0.055 \pm 0.006$ \\
\hline & & 1.0 & $1.3 \pm 1.5^{*}$ & $26.9 \pm 1.0$ & $0.245 \pm 0.005$ \\
\hline & Vitamin C & 0.01 & $35.3 \pm 0.9$ & $88.2 \pm 5.8$ & $0.381 \pm 0.043$ \\
\hline
\end{tabular}

${ }^{1} \mathrm{AJN}$ : Achyranthes japonica Nakai, ${ }^{2} \mathrm{ABB}$ : Achyranthes bidentata Blume. ${ }^{3}$ ex: extract, ${ }^{4}$ fr: fraction. Data are presented as the mean \pm $\mathrm{SD}$ of three determinations. ${ }^{*}>0.05$ compared with counterpart of AJN or ABB.

Table 5. Comparison of the nitrite scavenging activity of hot water extracts and their fractions between Achyranthes japonica Nakai (Korea) and $A$. bidentata Blume (China)

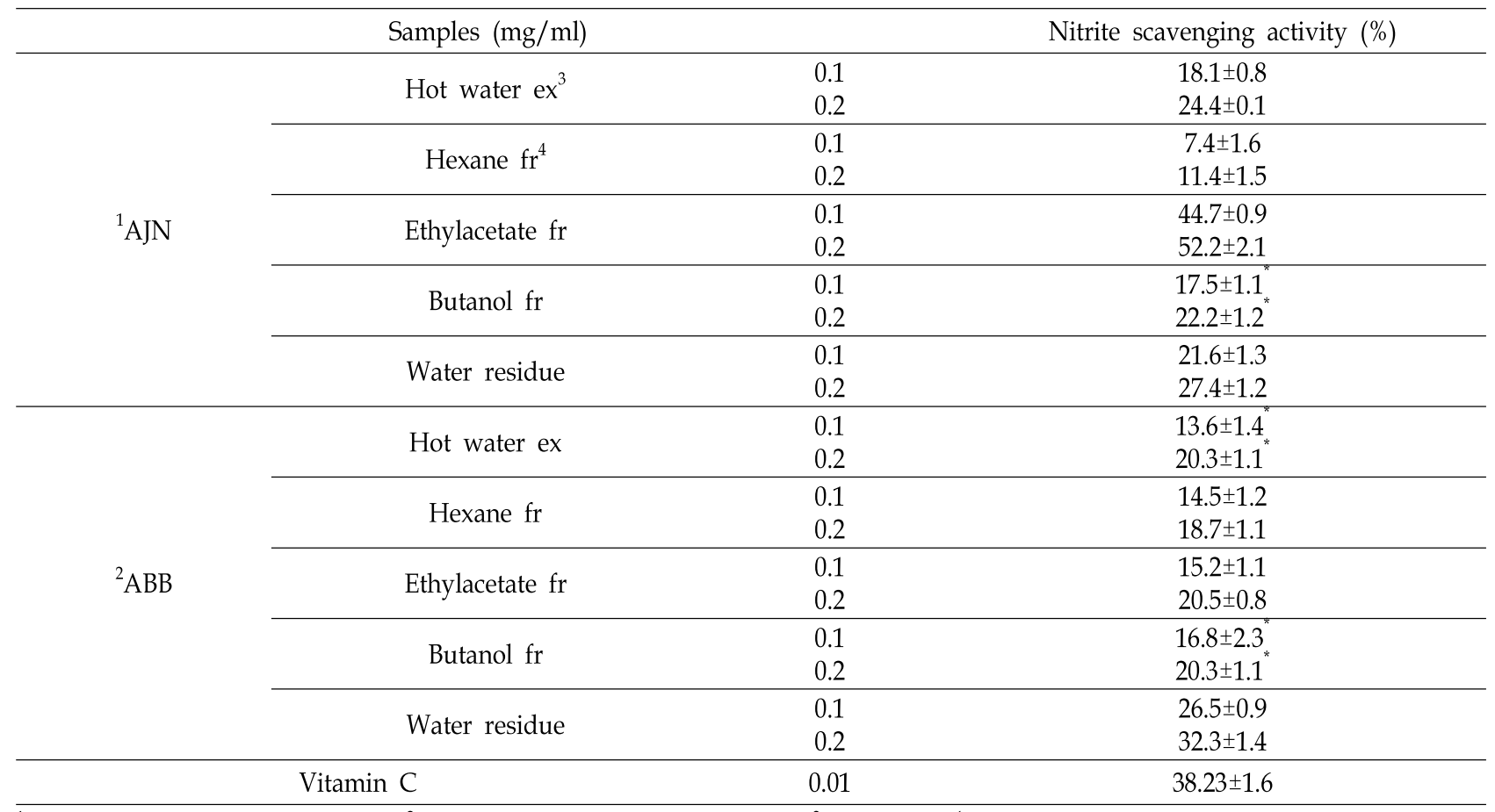

${ }^{1} \mathrm{AJN}$ : Achyranthes japonica Nakai, ${ }^{2} \mathrm{ABB}$ : Achyranthes bidentata Blume, ${ }^{3}$ ex: extract, ${ }^{4}$ fr: fraction.

Data are presented as the mean $\pm \mathrm{SD}$ of three determinations. ${ }^{*} p 0.05$ compared with counterpart of AJN or ABB. 
Table 6. Comparison of the in-vitro anti-diabetes activity of hot water extracts and their fractions between Achyranthes japonica Nakai (Korea) and $A$. bidentata Blume (China)

\begin{tabular}{|c|c|c|c|c|}
\hline & \multirow{2}{*}{ Samples $(\mathrm{mg} / \mathrm{ml})$} & & \multicolumn{2}{|c|}{$\begin{array}{c}\text { In-vitro anti-diabetes } \\
\text { activity }(\%)\end{array}$} \\
\hline & & & $\begin{array}{c}\text { Inhibition of } \\
\text { a-amylase }\end{array}$ & $\begin{array}{l}\text { Inhibition of } \\
\text { a-glucosidase }\end{array}$ \\
\hline \multirow{10}{*}{${ }^{1} \mathrm{AJN}$} & \multirow{2}{*}{ Hot water $\mathrm{ex}^{3}$} & 0.5 & $16.6 \pm 0.8$ & $11.3 \pm 1.7^{*}$ \\
\hline & & 1.0 & $27.2 \pm 1.3$ & $14.7 \pm 1.0^{*}$ \\
\hline & \multirow{2}{*}{ Hexane $\mathrm{fr}^{4}$} & 0.5 & $8.1 \pm 0.4$ & $9.3 \pm 1.4^{*}$ \\
\hline & & 1.0 & $15.7 \pm 0.9^{*}$ & $11.2 \pm 0.8$ \\
\hline & \multirow{2}{*}{ Ethylacetate fr } & 0.5 & $15.4 \pm 2.5$ & $9.3 \pm 1.6$ \\
\hline & & 1.0 & $23.4 \pm 0.4^{*}$ & $10.5 \pm 1.7$ \\
\hline & \multirow{2}{*}{ Butanol fr } & 0.5 & $7.5 \pm 1.1^{*}$ & $11.6 \pm 0.8$ \\
\hline & & 1.0 & $11.3 \pm 1.7$ & $14.5 \pm 0.9$ \\
\hline & \multirow{2}{*}{ Water residue } & 0.5 & $10.1 \pm 1.7$ & $3.4 \pm 2.7$ \\
\hline & & 1.0 & $12.7 \pm 0.1$ & $11.3 \pm 5.8$ \\
\hline \multirow{10}{*}{${ }^{2} \mathrm{ABB}$} & \multirow{2}{*}{ Hot water ex } & 0.5 & $5.6 \pm 1.5$ & $12.2 \pm 1.6^{*}$ \\
\hline & & 1.0 & $9.8 \pm 0.3$ & $14.0 \pm 0.5^{*}$ \\
\hline & \multirow{2}{*}{ Hexane fr } & 0.5 & $11.3 \pm 0.2$ & $11.1 \pm 1.6^{*}$ \\
\hline & & 1.0 & $14.3 \pm 0.7^{*}$ & $16.2 \pm 2.1$ \\
\hline & \multirow{2}{*}{ Ethylacetate fr } & 0.5 & $20.7 \pm 1.4$ & $-1.9 \pm 2.0$ \\
\hline & & 1.0 & $23.2 \pm 0.5^{*}$ & $-0.7 \pm 1.4$ \\
\hline & \multirow{2}{*}{ Butanol fr } & 0.5 & $15.4 \pm 1.0$ & $15.8 \pm 2.1$ \\
\hline & & 1.0 & $17.6 \pm 0.9$ & $17.3 \pm 1.5$ \\
\hline & \multirow{2}{*}{ Water residue } & 0.5 & $16.1 \pm 0.8$ & $13.5 \pm 0.1$ \\
\hline & & 1.0 & $19.5 \pm 1.1$ & $16.8 \pm 1.9$ \\
\hline & Acarbose & 0.1 & $49.4 \pm 0.6$ & $55.2 \pm 0.4$ \\
\hline
\end{tabular}

${ }^{1} \mathrm{AJN}$ : Achyranthes Japonica Nakai, ${ }^{2} \mathrm{ABB}:$ Achyranthes Bidentata Blume, ${ }^{3}$ ex: extract, ${ }^{4}$ fr: fraction. Data are presented as the mean $\pm \mathrm{SD}$ of three determinations. ${ }^{*} p 0.05$ compared with counterpart of $\mathrm{AJN}$ or $\mathrm{ABB}$.

내에서 동일 약재로 사용되고 있는 토우슬과 회우슬의 열수 추출물들은 추출효율과 성분에서 많은 차이가 있으며, 특히 이들의 분획물의 경우 성분 및 활성이 더욱 차이가 나타남을 제시하고 있다. 따라서 우슬의 항균, 항산화 및 항당뇨 활성을 이용한 천연물 신약 개발시에는 국내산 토우슬의 ethylacetate 분획이 적합하며, 우슬차 및 우슬식혜 제조시에는 토우슬의 열수 추출물이 적합함을 확인하였다.

\section{References}

1. Ahn, S. M., Ryu, H. Y., Kang, D. K., Jung, I. C. and Sohn, H. Y. 2009. Antimicrobial and antioxidant activity of the fruit of Prunus avium L. Korean J Microbiol Biotechnol 36, 195-200.

2. Bang, S. Y., Kim, J. H., Kim, H. Y., Lee, Y. J., Park, S. Y., Lee, S. J. and Kim, Y. 2012. Achyranthes japonica exhibits anti-inflammatory effect via NF- $\mathrm{kB}$ suppression and HO-1 in- duction in macrophages. J Ethnopharmacol 144, 109-117.

3. Cai, H., Choi, S. I., Lee, Y. M. and Heo, T. R. 2002. Antimicrobial effects of herbal medicine extracts on Staphylococcus aureus and Escherichia coli O157:H7. Korean J Biotechnol Bioeng 17, 537-542.

4. Choi, J. Y., Lee, C. H., Jang, J. B., Lee, K. S. and Lee, J. M. 2012. Inhibitory effects of Achyranthis radix extract mixed with hydrogel on osteoclast differentiation. J Oriental Obster Gynecol 25, 1-10

5. Jang, G. Y., Kim, H. Y., Lee, S. H., Kang, Y., Hwang, I. G., Woo, K. S., Kang, T. S., Lee, J. S. and Jeong, H. S. 2012. Effects of heat treatment and extraction method on antioxidant activity of several medicinal plants. J Korean Soc Food Sci Nutr 41, 914-920.

6. Jung, S, M., Choi, S. I., Park, S. M. and Heo, T. R. 2007. Antimicrobial effects of Achyranthes japonica Nakai extract against Clostridium difficile. Korean J Food Sci Technol 39, 564-568.

7. Kang, H. G., Hong, J. W., Han, H. J., Hwang, Y. Y., Jeong, J. Y. and Lee. K. N. 2004. Effects of methanol extract of radix Achyranthis bidentatae on cadmium inhalation toxicity in rat. Korean J Oriental Physiol Pathol 18, 1784-1794.

8. Kim, C. S. and Park, Y. K. 2010. The therapeutic effect of Achyranthis radix on the collagen-induced arthritis in mice. Korean J Herbology 22, 155-167.

9. Kim, H. K., Jeung, J., Park, S. J., Kang, S. H., Song, Y. S. and Lee, K. N. 2004. Effects of extract of radix Achyranthis bidentatae on cadmium inhalation toxicity in rats. Korean $J$ Oriental Physiol Pathol 18, 274-283.

10. Kim, J. H., Ki, J. Y., Ahn, J. Y., Park, H. J., Kim, H. J., Kwak, H. B., Ohm, J. M. and Kim, Y. K. 2010. Inhibitory effects of Achyranthis bidentatae radix on osteoclast differentiation and bone resorption. Korean J Herbology 25, 65-74.

11. Kim, J. I., Jang, H. S., Kim, J. S. and Sohn, H. Y. 2009. Evaluation of antimicrobial, antithrombin, and antioxidant activity of Dioscorea batatas Decne. Korean J Microbiol Biotechnol 37, 133-139.

12. Kim, J. M., Kang, D. H., Kim, J. H., Na, S. Y. and Ju, Y. S. 2007. A study on external and internal morphology in 4 kinds of Uie-Suel radix. Korean J Herbology 22, 71-79.

13. Kim, K. A., Lee, J. S., Park, H. J., Kim, J. W., Kim, C. J., Shim, I. S., Han, S. M. and Lim, S. 2003. The inhibitory effect of Achyranthes bidentata radix extracts on cytochrome P450-catalyzed reactions in human liver microsomes. Korean J Oriental Med 24, 40-46.

14. Kim, K. S. and Kim, H. 2011. Morphometrics and distribution of Achyranthes bidentata complex. Korean J Medicinal Crop Sci Apr 28, 86-87.

15. Kim, K. S., Seung, N. S., Kim, M. W., Pyo, B. S., and Baik, H. 1997. Micropropagation of Achyranthes japonica through axillary buds culture. Korean J Plant Tissue Culture 24, 357-360.

16. Kim, K. S., Shin Y. W., Kim, E. I., Kim, S. M., Lee, J. E. and Yoo, D. Y. 2005. The experimental study on antithrombotic activities of wuslsan. J Oriental Obster Gynecol 18, 110-126. 
17. Kim, M. S., Jeong, J. S., Lee, H. Y., Ju, Y. S., Bae, G. S., Seo, S. W., Cho, I. J., Park, S. J. and Song, H. J. 2011. The anti-inflammatory effect of Achyranthes japonica on lipopolysaccharide-induced inflammatory activity in murine macrophages. Korean J Herbology 26, 51-57.

18. Kim, S. H., Choi, E. J., Kim, D. H., Lee, K. Y., Lee, M., Baek, S. W., Kwak, S. J., Kang, T. S., Kim, Y. C. and Sung, S. H. 2008. Stability test of the extracts of Cimicfugae rhizoma, Achyranthis radix, Artemisia capillaris herba, mountain cotex radicis and Arecae semen for toxicity study. Korean $J$ Pharmacogn 39, 241-245.

19. Kim, S. J., Park, J. B., Kwon, Y. H., Park, K. K. and Choung, S. Y. 2002. The effect of Achyranthis radix extract on hard tissue regeneration. I Appl Pharmcol 10, 253-257.

20. Kim, Y. O., Lee, S. W. and Lee, S. E. 2009. Effect of Achyranthes japonica on carragenan-induced arthritis in rat model. Korean J Medicinal Crop Sci 17, 470-474.

21. Lee, Y. S., Kim, M. S., Kim, D. J. and Sohn, H. Y. 2013. A comparison of the components and biological activities of the ethanol extract of Achyranthes japonica Nakai and Achyranthes bidentata Blume. Korean J Microbiol Biotechnol 41, 416-424.

22. Lim, C. S., Li, C. Y., Kim, Y. M., Lee, W. Y. and Rhee, H. I. 2005. The inhibitory effect of Corus walteri extract against a-amylase. J Korean Soc Appl Biol Chem 48, 103-108.

23. Oh, T. W., Park, K. H., Lee, M. Y., Choi, G. and Park, Y. K. 2012. Effects of the water extracts from Achyranthes radix on serum-deprivation-induced apoptosis in PC12 cells and transient cerebral middle artery occlusion-induced ischemic brains of rats. Korean J Herbology 27, 77-83.

24. Park, J. S., Seong, N. S. and Lee, Y. J. 2007. Comparative study on the anti-oxidative effects of Achyranthes japonica radix, Achyranthes bidentata radix, and Cyathula radix. Korean $J$ Herbology 22, 155-167.

25. Singleton, V. L., Orthofer, R. and Lamuela-Raventos, R. M. 1999. Analysis of total phenols and other oxidation sub- strates and antioxidants by means of Folin-Ciocaleau reagent. Methods Enzymol 299, 152-178.

26. Sohn, H. Y., Ryu, H. Y., Jang, Y. J., Jang, H. S., Park, Y. M. and Kim, S. Y. 2008. Evaluation of antimicrobial, antithrombin, and antioxidant activity of aerial part of Saxifraga stolonifera. Korean J Microbiol Biotechnol 36, 195-200.

27. Valentina, U., Fabcic, J. and Stampar, F. 2007. Sugars, organic acids, phenolic composition and antioxidant activity of sweet cherry (Prunus avium L.). Food Chem 107, 185-192.

28. Wang, H., Tang, D. and Zhao, Y. 2013. Effect of dietary Achyranthes bidentata polysaccharide on immunity and antioxidant function of grass carp Ctenopharyngodon ldellus. Acta Hydrobiologica Sinica 37, 351-357.

29. Xie, F., Li, X., Sun, K., Chu, Y., Cao, H., Chen, N., Wang, W., Liu, M., Liu, W. and Mao, D. 2001. An experimental study on drugs for improving blood circulation and removing blood stasis in treating mild chronic hepatic damages. J Tradit Chin Med 21, 225-231.

30. Yang, L., Jiang, H., Wang, Q. H., Yang, B. Y. and Kuang, H. X. 2012. A new feruloyl tyramine glycoside from the roots of Achyranthes bidentata. Chin J Nat Med 10, 16-19.

31. Yoon, H. N., Yoon, Y. K., Jang, K. H., Kim, H. W., Lee, K. S., Lee, J. S., Lee, D. J. and Kim, J. B. 2009. Antioxidant and anticancer activities by different parts in Achyranthes japonica and Achyranthes bidentata. Korean J Medicinal Crop Sci 7, 385-386.

32. Zhao, B. T., Jeong, S. Y., Moon, D. C., Son, K. H., Son, J. K. and Woo, M. H. 2012. High performance liquid chromatography used for quality control of Achyranthis radix. Arch Pharm Res 35, 1449-1455.

33. Zhu, X., Pan, Y., Zheng, L., Cui, L. and Cao. Y. 2012. Polysaccharides from the Chinese medicinal herb Achyranthes bidentata enhance anti-malarial immunity during Plasmodium yoelii 17XL infection in mice. Malar J11, 49-56. 


\section{초록 : 토우슬과 회우슬의 열수 추출물의 성분 및 생리활성 비교}

이예슬·김미선·권하영·손호용*

(안동대학교 식품영양학과)

식용 및 약용으로 사용 가능한 우슬은 국가마다 다른 기원식물을 가지고 있으며, 국내에서는 토우슬 및 회우슬 을 사용하도록 규정하고 있다. 현재까지 다양한 우슬에 대한 많은 연구가 이루어져 왔으나, 식용으로 이용되고 있는 토우슬과 회우슬의 열수 추출물에 대한 비교연구는 전무한 상태이다. 본 연구에서는 기능성 우슬차 및 우슬 식혜 제조를 목표로, 토우슬과 회우슬의 열수 추출물과 이들의 순차적 분획물을 조제하여 각각의 유용성분 및 in-vitro 항균활성, 항산화, 및 항당뇨 활성을 비교 평가하였다. 그 결과, 회우슬의 열수 추출물은 토우슬보다 수용 성 당류 및 다양한 폴리페놀 성분을 다량 포함하고 있으며, 토우슬보다 높은 명도와 낮은 황색도를 나타내었다. 항세균 활성 평가에서는 토우슬의 ethylacetate 분획과 회우슬의 n-hexane 분획에서 우수한 활성이 나타났으며, 활성 음이온, 활성 양이온 및 nitrite 소거능 및 환원력 측정의 항산화 활성 평가결과, 토우슬 추출물이 회우슬보다 우수하며, 특히 토우슬의 ethylacetate 분획에서 강력한 항산화 활성을 확인하였다. 또한 in-vitro 항당뇨 활성평가 결과, 토우슬 및 회우슬의 ethylacetate 분획에서 우수한 a-amylase 저해활성을, 각각의 butanol 분획에서 aglucosidase 저해활성을 확인하였다. 본 연구결과는 토우슬과 회우슬의 열수 추출물들은 추출효율과 성분에서 많 은 차이가 있으며, 특히 이들의 분획물의 경우 성분 및 활성이 더욱 차이가 나타남을 제시하고 있다. 따라서, 우슬 의 항균, 항산화 및 항당뇨 활성을 이용한 천연물 신약 개발시에는 토우슬의 ethylacetate 분획을 이용하는 것이 적합하며, 우슬차 및 우슬식혜 제조시에는 토우슬의 열수 추출물이 적합함을 확인하였다. 